for her researches on the influence of the nervous system on regeneration. The Petit d'Ormoy Prize (Mathematical Sciences) to Jules Drach for the whole of his work. The Petit d'Ormoy Prize (Natural Sciences) to Maurice Caullery for the whole of his work in zoology and biology. The Saintour Prize to Arnaud Denjoy for his works on the calculus of primitive functions. The Lonchampt Prize between Albert Frouin and Mlle. Maylis Guillaumie (200o francs) for their memoir entitled "La nutrition carbonée du bacille tuberculeux," and Paul Cristol (Iooo francs) for his work on cancerous tissues. The Wilde Prize (in equal parts) between Raymond Jouaust for his researches on photometry and radiotelegraphy and René Mesny for his researches on radiogoniometry and short Hertzian waves. The Gustave Roux Prize to Edmond Sollaud for his researches on the embryogeny of the crustaceans. The Thorlet Prize to Adolphe Richard.

Special Foundations.-The Lannelongue Foundation between Mmes. Cusco and Rück. The Laplace Prize to D. J. L. Bichelonne. The L. E. Rivot Prize between D. J. L. Bichelonne (750 francs), M. E. P. Pascal (750 francs), P. C. Adam (50o francs), and R. A. M. Lehuédé (500 francs).

GRANTS FOR SCIENTYFIC RESEARCH.-The following grants for research were announced:

The Tremont Foundation to Alexandre Meunier for his cartographical work on French Western Africa. The Gegner Foundation to Léon Bultingaire for his work in connexion with the preparation and publication of the catalogue of scientific publications in the libraries of Paris. The Hirn Foundation to Georges Corroy (2500 francs) for the cost of publication of a work on stratigraphy. The Becquerel Foundation to André Danjon for his astronomical works.

The Loutreuil Foundation.--I. Grants to establishments named by the founder:

(I) The National Museum of Natural History Louis Mangin (80oo francs) for the maritime laboratory of the Museum. Désiré Bois (400o francs) for the publication of the third volume of a guide to the collections of plants cultivated at the Museum.

(2) The National Veterinary School of Alfort I2, ooo francs to the library of this establishment for the purchase of books and more especially of periodicals.

(3) The National Veterinary School of Lyons. Joseph Basset (3000 francs) to pursue his researches on a new method of vaccination for anthrax and on the infectious diseases of the dog. Gabriel Marotel (I0oo francs) for the continuation of his researches on the treatment of the parasitic diseases of animals. L. Jung (I500 francs) for pursuing his researches on the rôle of fats in the utilisation of food albumen and on the mechanism of rumination and vomiting. Armand Tapernoux (Iooo francs) to continue his researches on the hydrogen ion concentration of biological liquids, particularly of milk. M. Tagand (IOoO francs) to enable him to undertake, under the direction of M. Lesbre, researches on teratogenesis in various domestic mammals.

(4) The National Veterinary School of Toulouse Jules Girard and Pierre Pons (2000 francs) for the continuation and development of their researches on the factors modifying growth (temperature, special diet, castration). P. Bru (Iooo francs) for researches on pulmonary emphysema in comparative pathology. Charles Hervieux (Iooo francs) for researches on the putrefaction of food.

II. Grants to establishments admitted for one year by the President. Conservatoire National des Arts et Métiers. Jules Lemoine (2000 francs) for the purchase of apparatus for the physical laboratory. Gabriel Koenigs ( 5 oo francs) for the translation of American patents concerning various mechanical arrangements.

III. Independent grants. Jules Barthoux (4500 francs) for mineralogical researches in Algeria. General Sebert (5000 francs) for the publication of documents relating to the creation of the Office central de documentation technique et industrielle. Jacques Chevalier (Iooo francs) for the purchase of apparatus for researches on experimental psychology at the new laboratory at the University of Grenoble. The Comité français de géodésie et géophysique (Section 6. Atmospheric electricity), I 4, oao francs. Mme. Yves Delage (400o francs) for the publication of a volume of "L'Année biologique." René Dubrisay (3000 francs) for the purchase of apparatus to pursue his researches in capillary chemistry. Louis Dunoyer ( 13,000 francs) to pursue his researches on certain problems relating to modern methods for the measurement of high vacua. The Fédération française des Sociétés de Sciences naturelles (700o francs) as a new contribution to the publication of the. "Faune de France." Edmond Friedel (2500 francs) for his researches on the diffraction of the $\mathrm{X}$-rays by smectic bodies. Pierre Lesne (200o francs) for the pursuit of his researches on the coleopterological fauna of peat. Charles Marie (500o francs) for assisting the publication of the annual tables of constants of chemistry, physics, and technology. Charles Moureu (400o francs) for the purchase of a new type of bomb calorimeter. The Marseilles Observatory (30oo francs) for the publication of the Journal des Observateurs. Em. Passemard (300o francs) for geological exploration in Syria. Jean Tilho (4000 francs) for the publication of maps resulting from his explorations of Tibesti, Borkou, Erdi, and Ennedi. J. Tissot (500o francs) for assisting the publication of a work concerning the constitution of animal and plant organisms. Mlle. $\mathrm{X}$. Trouard-Riolle for researches in genetics. Père Lejay to complete his researches on atmospheric electricity.

(The total grants from the Loutreuil Foundation given this year amount to 124,500 francs.)

The Bouchard Foundation to Henry Cardot for his work on adaptation to change of environment, heredity, Protozoa, and micro-organisms.

\title{
Annual Meeting of the Geographical Association.
}

"THE world about us is the greatest of all laboratories, and Nature is the greatest demonstrator." Even by the wayside, to and from school, as Prof. J. L. Myres showed, we may see processes in operation shaping the geography of the homeland and illustrating the geography of other lands. The rhythmic flow of a river, as elaborated by Dr. Vaughan Cornish, offers ample scope for training in scientific observation. Only by seeing can the eye be trained to appreciate the complex of Nature and man, the adjustment of life-social, economic and political--to its physical environment.
Sir Halford Mackinder stressed that description must be the central fact in the teaching of geography. Material must be obtained before there can be any study of causation. To describe truly, artistically and with a true sense of proportion is to reach the highest art, and such description is essential to the appreciation of a regional organisation and entity. On these grounds, Sir Halford placed geography among the arts rather than among the sciences, though, as Prof. Lyde pointed out, artistic description implies scientific method.

Regional description demands, one might almost

NO. 2934, VOL. I I 7] 
say presupposes, a cadre or framework. Prof. P. M. Roxby dealt with the concept of natural regions in the teaching of geography, drawing his illustrations from China. The land frontiers, regarded as a zone rather than a political line, separate major regions differing from each other physically and biologically no less than culturally and economically. This difference between China and her neighbours being greater than the difference between the sub-regions of China, makes for unity in spite of its regional diversity. The major sub-regions also-the North China plain, the lower Yang-tze basin, Szechwan, south-east China and the highlands of Yunnanreveal the same coincidence, broadly speaking, of natural and cultural divisions. Here, then, is a cadre, apparently permanent, giving definition to the geographical region with its internal complex and its external relationships.

Mr. A. G. Ogilvie outlined the extent to which such studies have been carried in South America and Africa and defined broadly the line upon which future geographical research must proceed. In both continents rapid progress is being made in topographic surveys and in the production of maps adequate for the needs of research workers. But much remains to be done. Under the auspices of the American Geographical Society much geographical work has been done in South America and more is being undertaken. In Africa little geographical research has as yet been carried out, especially in British territory.

Sir John Russell, in his account of "Cotton and the Nile," gave geographers two illustrations of great interest in the complexity and change of regional activities. Naturally the Anglo-Egyptian Sudan offers an important field for extensive cotton cultivation. Can the Nilotic tribes be induced to change their mode of life and grow cotton for the European market? In Egypt, on the other hand, a very distressing situation has arisen. After the expenditure of millions of pounds sterling on great schemes of irrigation, the land has begun to deteriorate quickly. For the first time in the long history of Egypt, it has been necessary to import fertilisers.
Egypt is now a large buyer of nitrate of soda for the growing of crops.

Geographical economics, a term applied to the study of economics on a regional or geographic basis, forms one of the most important and most urgent fields for research. What are the fundamental causes, for example, why Malaya and British Guiana, comparable in size, position, climate and fertility of soil, should differ so widely in their total population and the export of domestic products? One has a population of $3,300,000$ with export value of 78,7 I $4,225 l$. (I923), the other a population of 300,000 and exportvalue of $3,757,647 l$. Thisillustration, quoted by $\mathrm{Mr}$. Ormsby Gore, served as an introduction to his presidential address on " The Economic Geography of the British Empire." Under present conditions, some regions are primary producing countries, others are manufacturing. The two are complementary and both require that their economic life should be studied on a regional or geographic basis, however fully trade statistics may be studied in the abstract. To many statesmen in I763, Guadaloupe with its slaves and sugar appeared of far greater worth than the vast forest and prairie lands of Canada because the potential geographic value was not suspected. The observations of a trained geographer capable of getting the economic survey away from a narrow view of economics on to a much wider plane are of immense value, not merely to those engaged in administration, but also for those engaged in commerce. Unfortunately, little has as yet been done in the British Empire in this direction. Innumerable factors enter into an acceleration of primary production with the consequent increase of purchasing power of manufactured goods. Even in manufacturing countries, Sir Richard Gregory pointed out, inventive genius and adaptability may serve or create new needs and thus maintain or even enlarge the volume of trade between manufacturing and primary producing countries.

Altogether the papers presented at the annual meeting of the Geographical Association on January 7-9 furnished an excellent series illustrative of the theory and practice of geography.

\section{Geodetic Observations in the United States of America.}

$\Delta \mathrm{N}$ official coastal survey of the United States was first authorised under President Jefferson in I 807 , and since that date, with some vicissitudes, continual progress has been made in the survey of the country, both coast and inland. The Coast Survey, on account of its extended work, was renamed the Coast and Geodetic Survey, as now, in I 878. Besides the work done by this department, determinations of latitude, longitude, and azimuth have been made at various times by the U.S. Lake and Geological Surveys, the U.S. General Land Office, the U.S. and Canada Boundary Commission, the U.S. Army, and other bodies. Some of these determinations have hitherto remained unprinted, while others are scattered throughout many reports. The Coast and Geodetic Survey has therefore collected them all in one volume and made them readily and permanently available for scientific purposes. ${ }^{1}$

The preparation of the volume has been made by Sarah Beall, mathematician to the Survey, who acknowledges the help given by Dr. Bowie, chief of the Division of Geodesy, and all the other members

${ }^{1}$ Department of Commerce: U.S. Coast and Geodetic Survey. Serial No. 283. "Astronomic Determinations by United States Coast and Geodetic Survey and other Organizations." By Sarah Beall. Special Publication No. I Io, fp. $\mathrm{v}+337+\mathbf{r} 3$ plates. (Washington: Government Printing Office, r925.) 80 cents. of the staff of this Division. The compilation has been done in an admirably workmanlike fashion, with concise but adequate historical introductions and descriptions of the various classes of observations. There are four chapters dealing respectively with longitudes, latitudes, azimuths, and deflexions of the vertical, followed by a final chapter (occupying rather more than half the volume), giving detailed particulars of the stations. In each case the principal instruments and methods of observation and computation are described and illustrated, and the other relevant facts are summarised.

For a volume of this kind the letterpress contrives to be surprisingly interesting. The bulk of the volume, apart from the final chapter, is naturally devoted to tabular matter; the results (both as observed, and after making the various necessary adjustments) are given in order of date, the probable errors being indicated, except in the case of the deflexions of the vertical. Reference to any individual station is facilitated by a comprehensive index to stations. All those who have occasion to make use of geodetic data for the United States will feel grateful to the author, and to Dr. Lester Jones, the Director of the Survey, for this very valuable collected work.

$$
\text { NO. 2934, VOL. I I } 7 \text { ] }
$$

